\title{
The neonatal Fc receptor is expressed by human lymphocytes
}

\author{
K van Bilsen ${ }^{1,2^{*}}$, J Bastiaans ${ }^{2,3}$, W A Dik², E F De Haas ${ }^{2}$ S G Baarsma, R W Kuipers, P M van Hagen ${ }^{1,2}$ \\ From 5th European Workshop on Immune-Mediated Inflammatory Diseases \\ Sitges-Barcelona, Spain. 1-3 December 2010
}

\section{Introduction}

The neonatal Fc receptor (FcRn) is an MHC class I like receptor that binds immunoglobulin $\mathrm{G}$ (IgG) in acidic environment (mainly endosomes). The FcRn protects IgG from lysosomal degradation, controls its transport between cell layers and extends IgG serum half-life [1]. It has been shown that the FcRn is expressed by many human cells including APCs and monocytes [2]. Thus far FcRn expression by human lymphocytes has not been proven.

\section{Aim}

In this study we examined FcRn expression in isolated mononuclear cells derived from freshly harvested PBMCs.

\section{Methods}

Freshly isolated PBMCs were obtained from three healthy volunteers and one buffycoat. NK, B, monocyte and CD4 + and CD8+ cell subsets were sorted by flow cytometry. FcRn and beta-2-microglobulin $(\beta 2 \mathrm{M})$ mRNA levels were determined by RQ-PCR. FcRn protein expression from PBMCs obtained from a buffycoat was analyzed by Western blot studies.

\section{Results}

RQ-PCR revealed expression of FcRn and B2M mRNA in $\mathrm{B}, \mathrm{CD} 4+$ and CD8+ cells and monocytes in all three RPE cultures. Western blot analysis demonstrated that mRNA expression in PBMCs from a buffycoat co-existed with FcRn protein expression.

\section{Conclusions}

Apart from monocytes, human B, CD4+ and CD8+ cells express low levels of FcRn.

\section{Author details}

${ }^{1}$ Department of Internal Medicine, Erasmus University Medical Center, Rotterdam, The Netherlands. ${ }^{2}$ Department of Immunology, Erasmus University Medical Center, Rotterdam, The Netherlands. ${ }^{3}$ Rotterdam Eye Hospital, Rotterdam, The Netherlands.

Published: 25 November 2010

\section{References}

1. Roopenian DC, Akilesh S: FcRn: the neonatal Fc receptor comes of age. Nat Rev Immunol 2007, 7(9):715-25.

2. Zhu X, Meng G, Dickinson BL, Li X, Mizoguchi E, Miao L, Wang Y, Robert C, Wu B, Smith PD, Lencer WI, Blumberg RS: MHC class I-related neonatal FC receptor for lgG is functionally expressed in monocytes, intestinal macrophages, and dendritic cells. J Immunol. 2001, 166(5):3266-76.

doi:10.1186/1479-5876-8-S1-P1

Cite this article as: van Bilsen et al:: The neonatal Fc receptor is expressed by human lymphocytes. Journal of Translational Medicine 2010 8(Suppl 1):P1.

Department of Internal Medicine, Erasmus University Medical Center,

Rotterdam, The Netherlands

Full list of author information is available at the end of the article 